\title{
PROFIL DAYA TAHAN JANTUNG PARU, FLEKSIBILTAS, KELINCAHAN DAN KESEIMBANGAN MAHASISWA ILMU KEOLAHRAGAAN FIK UNY
}

\author{
Krisnanda Dwi Apriyanto ${ }^{1}$ \\ ${ }^{1}$ Ilmu Keolahragaan, Fakultas Ilmu Keolahragaan, Universitas Negeri Yogyakarta \\ Jl. Colombo No. 1, Karangmalang, Depok, Sleman, Daerah Istimewa Yogyakarta, Indonesia. \\ krisnanda.da@uny.ac.id
}

\begin{abstract}
Abstrak
Setiap orang menginginkan status kebugaran jasmani yang baik. Untuk mendapatkan kebugaran jasmani yang baik, salah satu alternatif cara yang paling efektif dan aman adalah dengan olahraga atau latihan. Status kebugaran jasmani seseorang dapat dikategorikan baik atau tidak, maka perlu dilakukan suatu pengukuran. Studi ini bertujuan untuk menggambarkan profil kebugaran jasmani mahasiswa IKOR A 2017 yang meliputi: daya tahan jantung paru, fleksibilitas, kelincahan dan keseimbangan. Subjek dalam studi ini adalah mahasiswa IKOR A angkatan tahun 2017 sejumlah 23 mahasiswa. Instrument yang digunakan dalam studi ini adalah multistage fitness test (MFT) untuk mengukur daya tahan jantung paru, sit and reach untuk mengukur fleksibilitas, Illinois agility run test untuk mengetahui kelincahan, dan standing stork untuk mengetahui keseimbangan. Hasil studi pada multistage fitness test menunjukkan 43,6\% memiliki kategori kebugaran jantung paru yang kurang. Hanya satu mahasiswa $(4,3 \%)$ yang indeks kebugaran jantung parunya dalam kategori sangat baik, Pada komponen fleksibilitas hasil menunjukkan bahwa 52,2\% memiliki tingkat fleksibilitas yang sangat baik. Hasil pengukuran komponen kelincahan menunjukkan bahwa tidak ada mahasiswa yang meliliki tingkat kelincahan yang baik dan sangat baik. Sebagian besar mahasiswa memiliki tingkat kelincahan yang sedang yaitu sebesar $87 \%$, dan pada kategori keseimbangan didapatkan hasil 43,6\% mahasiswa memiliki tingkat keseimbangan yang sangat baik. Hasil studi menunjukkan bahwa komponen kebugaran jasmani daya tahan jantung paru dan kelincahan pada mahasiswa IKOR 2017 masih perlu ditingkatkan.
\end{abstract}

Kata Kunci: daya tahan jantung paru, fleksibiltas, kelincahan, keseimbangan, mahasiswa IKOR

\section{CARDIORESPIRATORY ENDURANCE, FLEXIBILITY, AGILITY AND BALANCE PROFILE OF SPORT SCIENCE STUDENT IN SPORT SCIENCE FACULTY UNIVERSITAS NEGERI YOGYAKARTA}

\begin{abstract}
Every person wants a good physical fitness status. To get good physical fitness, one of the most effective and safe alternatives is exercise. Physical fitness status can be categorized as good or poor if measurement is needed. This study aims to describe the physical fitness profile of sport science student class A 2017, which include: cardiorespiratory endurance, flexibility, agility and balance. The subjects in this study were sport science student class A 2017, who were 23 students. The instrument used in this study is a multistage fitness test (MFT) to measure cardiorespiratory endurance, sit and reach to measure flexibility, Illinois agility run test to determine agility, and standing stork to determine balance. The results of studies on the multistage fitness test showed $43.6 \%$ had a category of poor cardiorespiratory endurance fitness. Only one student (4.3\%) had an excellent cardiorespiratory endurance fitness index. The flexibility component showed that $52.2 \%$ had a excellent level of flexibility. The results of the agility showed that there were no students who have good and excellent agility levels. Most students have a moderate level of agility that is equal to $87 \%$, and in the balance category the results obtained are $43.6 \%$ students have a excellent level of balance. The study results showed that the
\end{abstract}


physical fitness component of cardiorespiratory endurance and agility in sport science student class $A$ 2017 needs to be improved.

Keywords: cardiorespiratory endurance, flexibility, agility, balance, sport science students

\section{PENDAHULUAN}

Kebugaran jasmani diartikan sebagai suatu kondisi jasmani yang bersangkutan dengan kemampuan fungsi tubuh dalam melakukan pekerjaan secara optimal dan efisien. Kebugaran jasmani sering dikaitkan dengan kegiatan manusia dalam melakukan pekerjaan dan bergerak. Secara umum, yang dimaksud kebugaran jasmani adalah kebugaran fisik (physical fitness), yaitu kemampuan seseorang melakukan kerja sehari-hari secara efisien tanpa mengalami kelelahan yang berarti sehingga masih mampu menikmati waktu luangnya. Kebugaran jasmani dapat diperoleh dengan berbagai cara, salah satu diantaranya adalah dengan aktivitas fisik atau berolahraga yang melibatkan komponen kebugaran jasmani dengan metode latihan yang teratur dan terukur. Kebugaran jasmani diperlukan oleh seseorang termasuk mahasiswa untuk melakukan aktivitas/pekerjaan sehari-hari. Bagi mahasiswa, kebugaran jasmani diperlukan untuk menghadapi segala aktivitas-aktivitas baik itu di lingkungan kampus atau di luar lingkungan kampus.

Kebugaran jasmani terbagi menjadi dua kategori yaitu kebugaran jasmani komponen keterampilan (skill related fitness) dan kebugaran jasmani komponen kesehatan (health related fitness) (Werner \& Sharon, 2010). Kebugaran komponen kesehatan meliputi kebugaran kardiorespirasi, komposisi tubuh, fleksibilitas, kekuatan otot dan daya tahan otot. Sedangkan kesegaran jasmani yang berhubungan dengan ketrampilan meliputi: (a) kecepatan, (b) kekuatan, (c) keseimbangan, (d) kelincahan, (e) koordinasi, dan (f) waktu reaksi (Sumintarsih, 2007).

Daya tahan jantung paru diartikan sebagai kemampuan paru-paru, jantung, dan pembuluh darah untuk mengirimkan oksigen dalam jumlah yang cukup ke dalam sel untuk memenuhi kebutuhan aktivitas fisik dalam waktu yang lama (Werner \& Sharon, 2010). Daya tahan jantung paru ditentukan oleh jumlah maksimal oksigen yang dapat dimanfaatkan tubuh manusia (pengambilan oksigen) per menit aktivitas fisik $\left(\mathrm{VO}_{2 \text { maks }}\right)$. Nilai ini dapat dinyatakan dalam liter per menit $(\mathrm{L} / \mathrm{min})$ atau mililiter per kilogram per menit $(\mathrm{mL} / \mathrm{kg} / \mathrm{menit})$. Untuk mengetahui status kebugaran jantung paru seseorang maka perlu dilakukan suatu perngukuran. Banyak tes pengukuran yang dapat digunakan untuk mengetahui status kebugaran, diantaranya: the 1.5Mile Run Test, the 1.0-Mile Walk Test, the Step Test, the Astrand Rhyming Test, multistage fitness test dan the 12-Minute Swim Test.

Fleksibilitas diartikan sebagai kemampuan gerak maksimal suatu persendian (Sumintarsih, 2007). Tingkat fleksibilitas seseorang dapat meningkat apabila sering dilatih, kemampuan ini meliputi otot, otot kerangka tubuh, dan sendi. Kravitz (2001), fleksibilitas atau kelentukan adalah daerah gerak otot-otot dan persendian tubuh. Meningkatnya kelentukan akan memperbaiki penampilan tubuh dan mengurangi kemungkinan cedera dalam menjangkau setiap gerakan. Fleksibilitas adalah jangkauan gerakan di mana tubuh dapat bergerak. Jangkauan gerak yang dilakukan secara normal adalah jangkuan gerak yang aman untuk dilakukan. Jadi kelentukan adalah kemampuan persendian tubuh yang meliputi elastisitas otot, tendon, ligamen, dan kualitas sendi untuk melakukan jangkauan gerak yang luas. Tingkat fleksibilitas seseorang dapat diketahui apabila dilakukan suatu pengukuran. Salah satu pengukuran yang dapat dilakukan untuk mengetahui tingkat fleksibilitas adalah dengan menggunakan sit and reach.

Keseimbangan merupakan kemampuan seseorang untuk mengontrol bagian-bagian dari tubuh dalam mempertahankan suatu posisi (Nurhasan, 2005). Keseimbangan untuk mempertahankan suatu posisi/diam biasa dilakukan dengan cara berdiri satu kaki dengan posisi 
tangan seperti kapal terbang. Keseimbangan tidak hanya diukur pada saat diam saja, melainkan keseimbangan pada saat bergerak juga dibutuhkan. Keseimbangan adalah kemampuan untuk mempertahankan ekuilibrium saat bergerak (Sharkey, 2003), keseimbangan tubuh sangat diperlukam seseorang untuk menjaga suatu posisi, baik saat diam atau bergerak, Salah satu pengukuran yang dapat dilakukan untuk mengetahui keseimbangan adalah dengan standing stork test.

Kelincahan diartikan sebagai kemampuan seseorang untuk mengubah arah dengan cepat sambil tetap mempertahankan kontrol tubuh (Sharkey, 2003). Kelincahan merupakan perpaduan antara kecepatan dan keseimbangan, sehingga saat mengubah posisi tubuh, kontrol tubuh tetap terjaga. Kelincahan adalah kemampuan dengan cara mengubah arah posisi tubuh ke segala arah dengan kecepatan dan ketepatan tinggi. Salah satu pengukuran yang dapat dilakukan untuk mengetahui kelincahan adalah dengan Illinois agility run test.

Memiliki status kebugaran jasmani yang baik merupakan keinginan dari setiap orang, termasuk mahasiswa. Semua kegiatan atau aktivitas yang dilakukan oleh mahasiswa baik itu di dalam kampus dan di luar kampus sangat dipengaruhi oleh tingkat kebugaran jasmani mahasiswa tersebut. Lebih khusus lagi mahasiswa Ilmu Keolahragaan, ketika berada di kampus mereka akan menghadapi perkuliahan baik itu di lapangan atau di ruangan yang jelas-jelas memerlukan status kebugaran yang baik agar mahasiswa mampu mengikuti perkuliahan dengan baik. Berdasarkan uraian singkat di atas maka penulis ingin mengetahui profil kebugaran jasmani mahasiswa ilmu keolahragaan kelas A tahun angkatan 2017, yang meliputi daya tahan jantung paru, fleksibilitas, kelincahan dan keseimbangan.

\section{METODE}

Studi ini merupakan penelitian deskriptif dalam menggambarkan kebugaran jasmani mahasiswa IKOR A 2017 yang meliputi: daya tahan jantung paru, fleksibilitas, kelincahan dan keseimbangan. Subjek dalam studi ini adalah mahasiswa IKOR A angkatan tahun 2017 sejumlah 23 mahasiswa. Studi dibuat tanpa membandingkan atau menghubungkan variabel satu dengan yang lainnya. Dalam pengambilan data, studi ini menggunakan metode survey dengan pengukuran untuk memperoleh data yang dibutuhkan. Instrument yang digunakan dalam studi ini adalah multistage fitness test (MFT) untuk mengukur daya tahan jantung paru, sit and reach untuk mengukur fleksibilitas, Illinois agility run test untuk mengetahui kelincahan, dan standing stork untuk mengetahui keseimbangan. Data yang diperoleh kemudian diolah secara deskriptif untuk mengetahui mean dan modus.

\section{HASIL DAN PEMBAHASAN}

\section{Data Hasil Multistage Fitness Test}

Hasil pengukuran daya tahan jantung paru pada mahasiswa IKOR A 2017 dengan menggunakan Multistage Fitness Test menunjukkan hasil yang kurang menyenangkan. Data hasil Multistage Fitness Test dapat dilihat pada tabel di bawah ini:

Tabel 1. Data Hasil Multistage Fitness Test

\begin{tabular}{|c|l|c|c|}
\hline No. & \multicolumn{1}{|c|}{ Kategori } & Jumlah & Persentase \\
\hline 1. & Sangat Baik & 1 & $4,3 \%$ \\
\hline 2. & Baik & 2 & $8,7 \%$ \\
\hline 3. & Sedang & 7 & $30,4 \%$ \\
\hline 4. & Kurang & 10 & $43,6 \%$ \\
\hline 5. & Sangat Kurang & 3 & $13 \%$ \\
\hline \multicolumn{2}{|r|}{ Jumlah } & 23 & $100 \%$ \\
\hline
\end{tabular}


Berdasarkan dari analisis data deskriptif, diperoleh data bahwa hampir separuh dari mahasiswa IKOR A 2017 yaitu 43,6\% memiliki kategori kebugaran jantung paru yang kurang. Hanya satu mahasiswa $(4,3 \%)$ yang indeks kebugaran jantung parunya dalam kategori sangat baik, 8,7\% berada dalam kategori baik, kategori sedang sebesar 30,4\%, dan kategori sangat kurang sebesar $13 \%$. Berdasarkan penelitian yang dilakukan oleh Sudibjo, Prasetyo, Sumarjo \& Rismayanthi (2019), hasil tes daya tahan jantung paru yang diperoleh mahasiswa IKOR 2017 serupa dengan yang didapatkan oleh adik tingkat mahasiswa IKOR 2018 dan 2019. Pengukuran dengan menggunakan instrumen lari 1600 meter menunjukkan hasil hanya satu mahasiswa IKOR angkatan 2018 yang memperoleh predikat sangat baik, 40\% mahasiswa IKOR 2018 berada dalam kategori baik sedangkan 42,9\% mahasiswa IKOR 2019 berada dalam kategori sedang. Hasil ini dapat dijadikan refleksi bagi mahasiswa IKOR seluruh angkatan pada khususnya untuk dapat memperbaiki segala aspek komponen kebugaran jasmani. Mengingat mereka sebagai akademisi dan praktisi olahraga harus mempunyai kompetensi yang memadai dibidangnya.

Daya tahan jantung paru ditentukan oleh jumlah maksimal oksigen yang dapat dimanfaatkan tubuh manusia (pengambilan oksigen) per menit aktivitas fisik $\left(\mathrm{VO}_{2 \text { maks }}\right)$ (Werner \& Sharon, 2010). Jumlah oksigen yang benar-benar digunakan tubuh saat istirahat atau selama latihan submaksimal $\left(\mathrm{VO}_{2}\right)$ atau maksimal $\left(\mathrm{VO}_{2 \text { maks }}\right)$ ditentukan oleh denyut jantung, stroke volume, dan jumlah oksigen yang dikeluarkan dari sistem pembuluh darah (untuk digunakan oleh semua organ dan jaringan tubuh, termasuk sistem otot) (Werner \& Sharon, 2010). $\mathrm{VO}_{2 m a k s}$ dipengaruhi oleh genetika, latihan, jenis kelamin, usia, dan komposisi tubuh. Meskipun latihan aerobik dapat membantu seseorang mencapai kebugaran kardiorespirasi yang baik atau sangat baik, hanya mereka yang memiliki komponen genetik yang kuat yang mampu mencapai tingkat kapasitas aerobik "elit" (60 hingga $80 \mathrm{~mL} / \mathrm{kg} /$ menit). $\mathrm{VO}_{2 \text { maks }}$ pada pria lebih tinggi 15 hingga 30 persen. Ini terkait dengan kandungan hemoglobin yang lebih besar, lemak tubuh yang lebih rendah, dan ukuran jantung yang lebih besar pada pria (jantung yang lebih besar memompa lebih banyak darah, dan dengan demikian menghasilkan volume stroke yang lebih besar) (Werner \& Sharon, 2010). $\mathrm{VO}_{2 \text { maks }}$ juga berkurang sekitar 1 persen per tahun mulai dari usia 25 . Namun, penurunan ini hanya 0,5 persen per tahun pada individu yang aktif secara fisik. Daya tahan jantung paru dapat dilatih dengan latihan yang sifatnya aerobik atau juga latihan beban, seperti yang dipaparkan oleh Nasrulloh, A., Prasetyo, Y., \& Apriyanto, (2018) bahwa latihan beban dapat dirancang untuk meningkatkan daya tahan paru jantung dan memperbaiki komposisi tubuh.

\section{Data Hasil Sit and Reach}

Berbeda dengan data hasil Multistage Fitness Test, Data Hasil Sit and Reach menunjukkan bahwa lebih dari separuh mahasiswa IKOR A 2017 yaitu 52,2\% memiliki tingkat fleksibilitas yang sangat baik, $17,4 \%$ berada dalam kategori baik, kategori sedang sebesar $13 \%$, kategori kurang sebesar $17,4 \%$ dan tidak ada mahasiswa yang berada dalam kategori sangat kurang. Data hasil Sit and Reach dapat dilihat pada tabel di bawah ini:

Tabel 2. Data Hasil Sit and Reach

\begin{tabular}{|c|l|c|c|}
\hline No. & \multicolumn{1}{|c|}{ Kategori } & Jumlah & Persentase \\
\hline 1. & Sangat Baik & 12 & $52,2 \%$ \\
\hline 2. & Baik & 4 & $17,4 \%$ \\
\hline 3. & Sedang & 3 & $13 \%$ \\
\hline 4. & Kurang & 4 & $17,4 \%$ \\
\hline 5. & Sangat Kurang & 0 & $0 \%$ \\
\hline \multicolumn{2}{r|}{ Jumlah } & 23 & $100 \%$ \\
\hline
\end{tabular}


Hasil pengukuran fleksibilitas dengan menggunakan bangku sit and reach hanya mampu mengukur fleksibilitas otot hamstring (belakang paha) dan pada tingkat lebih rendah otot-otot punggung bagian bawah. Tingkat fleksibilitas pada satu sendi berbeda dengan tingkat fleksibilitas pada sendi yang lainnya. Untuk dapat mengetahui tingkat fleksibilitas sendi secara keseluruhan maka harus dilakukan juga pengukuran yang lebih spesifik pada sendi yang ingin di ukur. Fleksibilitas dipengaruhi oleh berbagai faktor, diantarany: faktor genetik, aktivitas fisik. struktur sendi (bentuk tulang), tulang rawan, ligamen, tendon, otot, kulit, cedera jaringan, dan jaringan adiposa (lemak). Suhu tubuh, usia, dan jenis kelamin juga mempengaruhi fleksibilitas (Werner \& Sharon, 2010).

Memiliki fleksibilitas yang baik dapat meningkatkan kesehatan otot dan sendi. meningkatkan dan memelihara berbagai gerak sendi yang baik dapat meningkatkan kualitas hidup. Meningkatkan elastisitas otot dan jaringan ikat di sekitar sendi memungkinkan kebebasan bergerak yang lebih besar dan kemampuan individu untuk berpartisipasi dalam berbagai jenis olahraga dan aktivitas lainnya. fleksibilitas yang memadai juga membuat aktivitas hidup sehari-hari seperti memutar, mengangkat, dan membungkuk lebih mudah untuk dilakukan. Tetapi setiap orang harus tetap berhati-hati untuk tidak meregangkan sendi terlalu berlebihan (overstretch). Overstretch mampu memicu ketidakstabil sendi dan membuat sendi menjadi longgar yang dapat meningkatkan tingkat cedera termasuk subluksasi sendi dan dislokasi (Werner \& Sharon, 2010).

\section{Data Hasil Illinois Agility Run Test}

Data hasil Illinois agility run test menunjukkan bahwa tidak ada mahasiswa yang meliliki tingkat kelincahan yang baik dan sangat baik. Sebagian besar mahasiswa IKOR A 2017 memiliki tingkat kelincahan yang sedang yaitu sebesar $87 \%$, sisanya $13 \%$ berada dalam kategori sangat kurang. Data hasil Illinois agility run test dapat dilihat pada tabel di bawah ini:

Tabel 3. Data Hasil Illinois Agility Run Test

\begin{tabular}{|c|l|c|c|}
\hline No. & \multicolumn{1}{|c|}{ Kategori } & Jumlah & Persentase \\
\hline 1. & Sangat Baik & 0 & $0 \%$ \\
\hline 2. & Baik & 0 & $0 \%$ \\
\hline 3. & Sedang & 20 & $87 \%$ \\
\hline 4. & Kurang & 0 & $0 \%$ \\
\hline 5. & Sangat Kurang & 3 & $13 \%$ \\
\hline \multicolumn{2}{|c|}{ Jumlah } & 23 & $100 \%$ \\
\hline
\end{tabular}

Data di atas linear dengan penelitian yang dilakukan oleh Sudibjo, Prasetyo, Sumarjo \& Rismayanthi (2019) dengan subjek penelitian mahasiswa IKOR FIK UNY tahun angkatan 2018 dan 2019. Hasil menunjukkan sebagian besar berada pada kategori sedang dengan persentase mahasiswa IKOR 2018 sebesar 66.7\% dan IKOR 2019 sebesar 85.7\%. Kelincahan merupakan perpaduan antara kecepatan dan keseimbangan, sehingga saat mengubah posisi tubuh, kontrol tubuh tetap terjaga. Dalam kehidupan sehari-hari, kelincahan dibutuhkan untuk menghadapi situasi-situasi refleks dan mendadak yang membutuhkan respons yang cepat. Dalam dunia olahraga, kelincahan diperlukan untuk penguasaan teknik-teknik tinggi, sebagai contoh dalam sepatu roda. Kelincahan menjadi salah satu faktor penting untuk olahraga prestasi salah satunya sepatu roda (Saputra \& Indra, 2019). Kelincahan sangat diperlukan untuk dapat mengambil posisi saat pengambilan point di nomer pertandingan point race maupun untuk mendapatkan kemenangan. 


\section{Data Hasil Tes Standing Stork}

Berdasarkan hasil tes Standing Stork untuk mengetahui status keseimbangan seseorang, didapatkan hasil hampir separuh dari mahasiswa memiliki tingkat keseimbangan yang sangat baik yaitu sebesar 43,6\%, kategori kurang sebesar 17,4\%, sedangkan kategori baik, sedang dan sangat kurang sebesar 13\%. Data hasil tes Standing Stork dapat dilihat pada tabel di bawah ini:

Tabel 4. Data Hasil Tes Standing Stork

\begin{tabular}{|c|l|c|c|}
\hline No. & \multicolumn{1}{|c|}{ Kategori } & Jumlah & Persentase \\
\hline 1. & Sangat Baik & 10 & $43,6 \%$ \\
\hline 2. & Baik & 3 & $13 \%$ \\
\hline 3. & Sedang & 3 & $13 \%$ \\
\hline 4. & Kurang & 4 & $17,4 \%$ \\
\hline 5. & Sangat Kurang & 3 & $13 \%$ \\
\hline \multicolumn{2}{r|}{ Jumlah } & 23 & $100 \%$ \\
\hline
\end{tabular}

Mengutip hasil penelitian yang telah dilakukan oleh Saputra \& Indra (2019) pada atlet sepatu roda putra dan putri, kemampuan tes keseimbangan yang dilakukan dengan instrument yang sama yaitu Standing Stork menunjukkan hasil tes keseimbangan atlet sepatu roda putra dan putri sebagian besar masuk dalam kategori "baik sekali" sebanyak 12 atlet atau $100 \%$ dari total frekuensi. Komponen keseimbangan sangat dipengaruhi oleh tingkat keterlatihan seperti yang nampak dari hasil studi dengan hasil penelitian yang dilakukan oleh Saputra \& Indra (2019). Komponen keseimbangan menjadi salah satu kebutuhan dasar yang harus dimiliki oleh semua orang terlebih lagi atlet sepatu roda. Baiknya angka keseimbangan akan berdampak pada performa ketika latihan atau bertanding. Komponen keseimbangan dominan pada semua bentuk gerak pada cabang olahraga sepatu roda (Powel \& Svensson, 1996).

\section{SIMPULAN}

Berdasarkan studi yang dilakukan pada mahasiswa IKOR A 2017, maka dapat disimpulkan bahwa 43,6\% mahasiswa memiliki kategori kebugaran jantung paru yang kurang, $52,2 \%$ memiliki tingkat fleksibilitas yang sangat baik, tidak ada satupun mahasiswa yang meliliki tingkat kelincahan yang baik dan sangat baik dan 43,6\% mahasiswa memiliki tingkat keseimbangan yang sangat baik. Tingkat kebugaran jasmani dipengaruhi oleh berbagai faktor, diantaranya: aktivitas fisik, status gizi, istirahat, genetika, jenis kelamin, usia, dan komposisi tubuh. Dari hasil studi yang telah dilakukan, penulis menyarankan untuk semua pribadi khususnya mahasiswa IKOR A 2017 agar selalu menjaga dan meningkatkan status kebugaran jasmani untuk mendukung segala kemudahan dalam menjalani segala aktivitas.

\section{DAFTAR PUSTAKA}

Kravitz, L. (2001). Panduan Lengkap: Bugar Total. Jakarta: PT. RajaGrafindo Persada.

Nasrulloh, A., Prasetyo, Y., \& Apriyanto, K. D. (2018). Dasar-Dasar Latihan Beban. Yogyakarta: UNY Press.

Nurhasan. (2005). Aktivitas Kebugaran. Jakarta: Direktorat Pembinaan Sekolah Luar Biasa.

Powel, M. dan Svensson, J. (1996). In-Line Skating (Terjemahan). Jakarta: Rajagrafindo Persada. 
Saputra, B. A., \& Indra, N. A. (2019). Profil Kondisi Fisik Atlet Sepatu Roda Daerah Istimewa Yogyakarta. MEDIKORA, Vol. XVIII No. 2 Oktober 2019. Hal 70-78. FIK UNY.

Sharkey, B. J. (2003). Kebugaran dan Kesehatan. Penerjemah: Eri Desmarini Nasution. Jakarta: PT. RajaGrafindo Persada.

Sudibjo, P., Prasetyo, Y., Sumarjo \& Rismayanthi, C. (2019). Perbandingan Tingkat Kebugaran, Gambaran Tinggi Badan, Berat Badan, Serta Indeks Masa Tubuh (IMT) bagi Mahasiswa Program Studi Ilmu Keolahragaan FIK UNY Tahun Akademik 2018 dan 2019. MEDIKORA, Vol. XVIII No. 2 Oktober 2019. Hal 108-120. FIK UNY.

Sumintarsih. (2007). Kebugaran Jasmani untuk Lanjut Usia. Olahraga. Vol. 13, Th. XIII, No. 1. Hlm. 26-40.

Werner W.K. Hoeger, Sharon A. Hoeger. (2010). Principles and Labs for Physical Fitness, Seventh Edition. Wadsworth, Cengage Learning. USA: Yolanda Cossio Publisher. 